\title{
Blooming meal: flower eating by the Blue-crowned Trogon Trogon curucui
}

\author{
Gustavo Gonsioroski ${ }^{1 *}$, Ivan Sazima ${ }^{2}$, Marcos Augusto Rodrigues Silva ${ }^{3(\mathbb{1}}$ \& Flávio Kulaif Ubaid ${ }^{3}$ \\ ${ }^{1}$ Universidade Estadual do Maranhão, Centro de Estudos Superiores de Caxias, Programa de Pós-Graduação \\ em Biodiversidade, Ambiente e Saúde, Caxias, MA, Brasil. \\ ${ }^{2}$ Universidade Estadual de Campinas, Museu de Zoologia, Campinas, SP, Brasil. \\ ${ }^{3}$ Universidade Estadual do Maranhão, Centro de Estudos Superiores de Caxias, Departamento de Química e \\ Biologia, Laboratório de Ornitologia, Caxias, MA, Brasil. \\ *Corresponding author: gustavogonsioroski@hotmail.com
}

GONSIOROSKI, G., SAZIMA, I., SILVA, M.A.R., UBAID, F.K. Blooming meal: flower eating by the Bluecrowned Trogon Trogon curucui. Biota Neotropica 21(3): e20201154. https://doi.org/10.1590/1676-0611BN-2020-1154.

\begin{abstract}
Flowers provide birds with a range of dietary resources, although few data are available on flower eating for birds that have mixed diets. We report here a new food type for the Blue-crowned Trogon (Trogon curucui), describing two flower eating events. The individuals fed on the yellow trumpet tree flowers (Handroanthus spp.) at the peak of the dry season in the Cerrado and Pantanal biomes. The birds picked up the flowers by sally-glean flying and a brief hovering, and then perched on a nearby branch to swallow the flower whole. Florivory appears to be seasonal and, while a minor component of this species' diet, flowers may be an important alternative resource during periods when fruits are scarce.

Keywords: feeding behavior, flowers as food, Trogonidae, Cerrado, Pantanal.
\end{abstract}

\section{Refeição florida: consumo de flores pelo surucuá-de-barriga-vermelha Trogon curucui}

Resumo: As flores fornecem às aves uma variedade de recursos alimentares, embora poucos dados estejam disponíveis sobre o consumo de flores por aves de dieta mista. Relatamos aqui um novo item alimentar para o surucuá-de-barriga-vermelha (Trogon curucui), descrevendo dois eventos de ingestão de flores. Os surucuás se alimentaram das flores de ipê-amarelo (Handroanthus spp.) no ápice da estação seca nos biomas Cerrado e Pantanal. As aves apanharam as flores em voo "sally-glean" e em seguida pousaram em um ramo próximo para engoli-las por inteiro. A florivoria parece ser sazonal e embora seja um componente secundário da dieta desta espécie, as flores podem ser um recurso alternativo importante durante os períodos em que os frutos são escassos.

Palavras-chave: comportamento alimentar, flores como alimento, Trogonidae, Cerrado, Pantanal. 


\section{Introduction}

Trogonidae (Aves, Trogoniformes) are forest dwellers that include eight genera and 43 species with a Pantropical distribution, except in Australasia (Collar 2020). African species are exclusively insectivores, whereas the Asian and Neotropical species have mixed diets of arthropods and fruits, with occasional small vertebrate preys, although the exact composition of the diet varies considerably among the different taxa (Remsen et al. 1993, Sick 1997, Collar 2000, Pizo 2007, Winkler et al. 2020). For species of the genus Trogon, analyses of the stomach contents of 17 species revealed a mixed diet of arthropods and fruits (Schubart et al. 1965, Remsen et al. 1993).

Florivory (or floral herbivory) is defined as the consumption of all or part of the structure of a flower, which may damage the floral bud or mature flower prior to the development of the seed capsule (Burgess 1991). Floral components are an important feeding resource for many Brazilian birds (Silva and Rubio 2007, Parrini \& Raposo 2008, 2010, Parrini 2015). Nevertheless, the consumption of flowers by omnivorous birds and the importance of floral resources in their diets are still poorly understood. Most studies focus on the consumption of nectar for acquisition of nutrients, energy, and water (Silva 2019), typically without causing damage to the flowers (Parrini 2015). However, some studies describe feeding on petals and other floral components by several bird species (Sazima \& Sazima 2007, Silva \& Rubio 2007, Parrini \& Pacheco 2013, Parrini 2015, Silva 2019).

We describe herein two events of flower eating by the Blue-crowned Trogon, Trogon curucui, during the dry season in the Brazilian Cerrado savanna and Pantanal wetland biomes. This species is reported as having a typical Trogon diet of invertebrates and fruit (Remsen et al. 1993).

\section{Material and Methods}

The records from the Cerrado were obtained in the village of

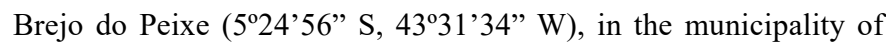
Parnarama, eastern Maranhão (Figure1). The observations were conducted in September, at the peak of the dry season, which coincides with the blooming of the yellow trumpet tree (Handroanthus sp.). The vegetation of the studied area is composed of extensive areas of Cerrado sensu lato, interspersed with tracts of Mauritia flexuosa palm swamps (veredas), small villages, and subsistence farmland. The local climate is highly seasonal, with a dry season from June to November and a rainy season from December to May. Another observation was obtained on the Transpantaneira highway (16 $20^{\circ} 21^{\prime}$ ' S, 56 $38^{\circ} 40^{\prime}$ ' W), in the municipality of Poconé, southern Mato Grosso. The vegetation of this studied area is composed of extensive swampland typical of the Pantanal, interspersed with tracts of gallery forests, and large cattleraising farms. The climate is highly seasonal, with a dry season from May to September and a rainy season from October to April (Tarifa 1986). The observations at both areas were conducted using Nikon 10x42 or Pentax 10x50 binoculars, and the photographs were taken with a Canon 7D camera.

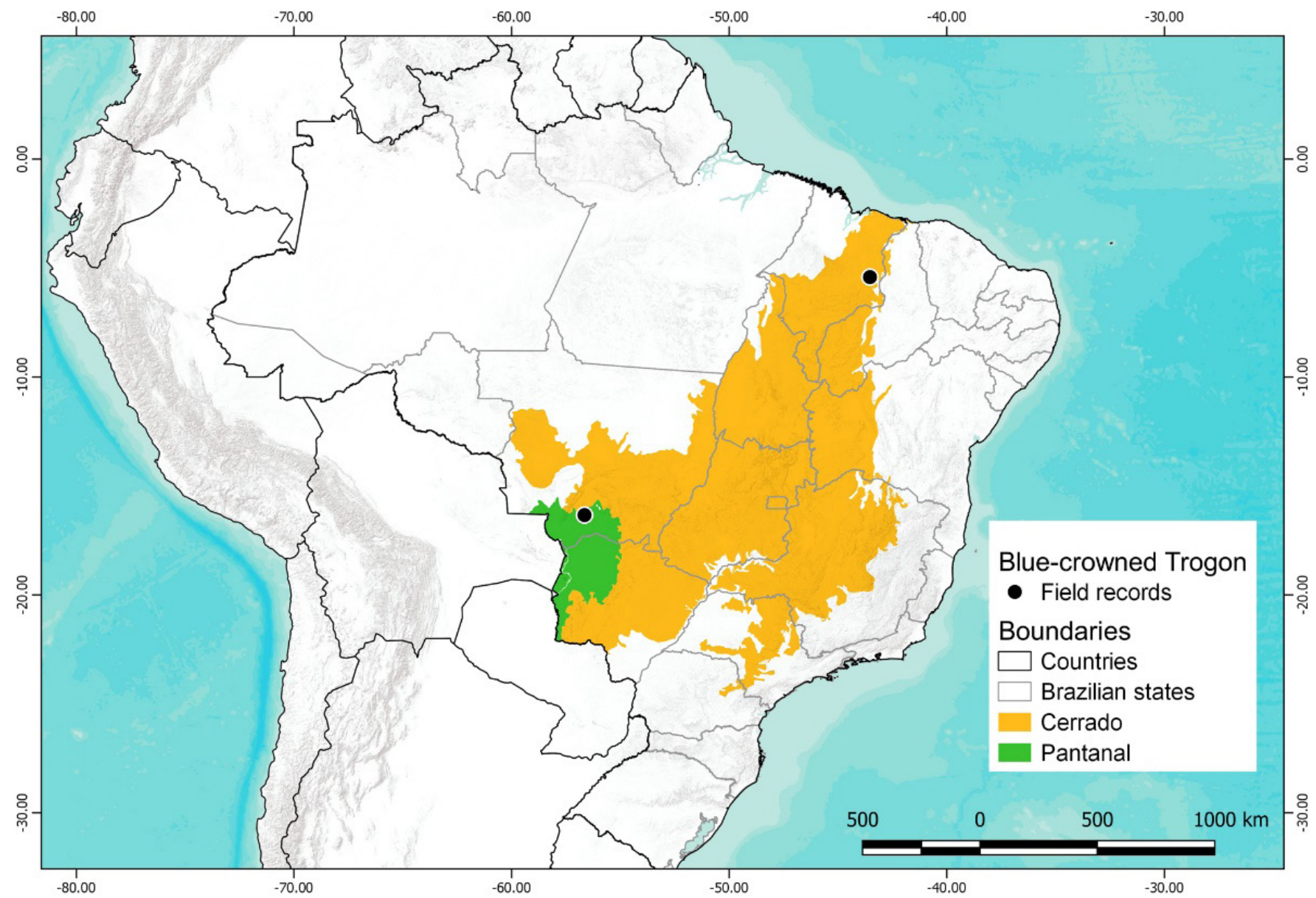

Figure 1. Map with the biomes Cerrado and Pantanal in Brazil, and the two field records of Blue-crowned Trogon (Trogon curucui) consuming trumpet tree (Handroanthus spp.) flowers. 


\section{Results}

On the Transpantaneira highway, on September 1982, at approximately 13:00 h, a pair of T. curucui was observed on a full blooming yellow trumpet tree (Handroanthus cf. ochraceus). The two birds were perched near one another and flew towards a flowering branch three or four times, using a sally-glean flight and picked a flower while hovering briefly. The birds then returned to their perch to swallow the flower whole. The female was observed picking and swallowing two flowers, while the male did this once before the pair left the perch and disappeared from view.

At the village of Brejo do Peixe, at 10:40 h on 9 September 2019, a flock of six Blue-crowned Trogon individuals was observed moving in the crown of a yellow trumpet tree (Handroanthus sp.) in full bloom. During the intense movements of the individuals among the crowns of the trees adjacent to the trumpet tree, a female Blue-crowned Trogon was observed carrying a yellow flower in its bill. Afterwards the flower was swallowed whole. Subsequently, a male was observed perching alongside a number of flowers and then descended in a short, rapid flight to collect a flower after a sally-glean maneuver, which consisted of swooping down onto a food item and capturing it in a brief hovering. The bird then perched in an adjacent tree and swallowed the flower whole (Figure 2).

\section{Discussion}

Our observations validate and document flower eating for the Bluecrowned Trogon, Trogon curucui, an apparently uncommon feeding behavior among Trogonidae. In an observational dietary study of three Trogon species in the Atlantic Forest, a single unidentified flower was eaten by a Greenbacked Trogon T. viridis individual during the dry season (Pizo 2007). On the other hand, the Cuban Trogon Priotelus temnurus seems to feed mostly on flowers, besides fruits and insects (Collar 2020).

Many Trogon species, including T. curucui, have a mixed diet composed mainly of fruits and arthropods. Schubart et al. (1965) analyzed 10 individuals of $T$. curucui (including T. variegatus), and found that $60 \%$ of the stomach contents were composed exclusively by arthropods while $40 \%$ had a mix of arthropods, fruits, seeds, and plant tissue. Remsen et al. (1993) analyzed 36 individuals and found that $52.8 \%$ of the stomach contents was composed by arthropods only, while $44.4 \%$ contained a combination of fruits and arthropods $(2.8 \%$ contained unidentified material).

While feeding on flowers, trogons and other birds may obtain a considerable combination of nutrients and sugars, such as glucose, fructose, and saccharose, particularly when fleshy fruits are scarce (Baker \& Baker 1983, Terborgh 1986, Galetto \& Bernardello 2003). Indeed, the flowers of trumpet trees (Handroanthus and Tabebuia) produce nectar with a high (23-30\%) concentration of sugars (Barros 2001; Souza et al. 2004). Handroanthus ochraceus blooms profusely for about one month during the dry season, and the time of the trogon feeding event recorded at Parnarama coincided with the 11:00 h peak of nectar concentration recorded for H. ochraceus and Tabebuia aurea (Barros 2001). In addition to making available an important alternative source of nutrients and energy, flowers may meet the birds' requirements for water, a scarce resource in the dry season (Mlcek \& Rop 2011, Silva et al. 2015, Silva 2019). The fleshy petals of Acca sellowiana may be an important nutritional resource for nestlings of the Sayaca Tanager Thraupis sayaca, the Chestnut-backed Tanager Stilpnia preciosa, and other passerines as well, when fruits are scarce (Sazima \& Sazima 2007).

The consumption of flowers is considered an opportunistic behavior in many birds and recorded mostly during the dry season when the availability of fruit and water is reduced (Parrini 2015, Silva 2019). Floral resources can be exploited in a number of ways, both destructive and non-destructive. Hummingbirds (Trochilidae) and a number of passeriforms feed on nectar and act as pollinators without changing the flower structure (Parrini \& Raposo 2010), whereas some species of Cracidae, Psittacidae, Ramphastidae, Thraupidae, and Icteridae are known to be flower predators (Ragusa-Netto 2005, Parrini \& Pacheco 2013, Parrini 2015, Mendes et al. 2017, Valtuille et al. 2017).

Primarily frugivorous birds may also occasionally include flowers in their diets, independently of the scarcity of fruit, as is the example of the Saffron Toucanet Pteroglossus bailloni in the Brazilian Atlantic Forest, and the Emerald Toucanet Aulacorhynchus prasinus in Costa Rica (Riley \& Smith 1986, Galetti et al 2000). It thus seems that at least some toucans may feed regularly on non-fruit foods, even if in small amounts, in particular during the breeding season (Riley \& Smith 1986). However, the Toco Toucan Ramphastos toco appears to eat flowers opportunistically in the Pantanal biome (Ragusa-Netto 2006).

In the Pantanal, Blue-throated Piping-Guan Pipile cumanensis regularly eats the flowers of the pink trumpet tree (Handroanthus impetiginosus) during the dry season, when it may congregate in blooming trees together with Chaco Chachalaca Ortalis canicollis, Barefaced Curassow Crax fasciolata, and Chestnut-bellied Guan Penelope ochrogaster (Del Hoyo et al. 2020). In the Pantanal, which has an intense dry season, the Yellow-chevroned Parakeet Brotogeris chiriri, Peach-fronted Parakeet Eupsittula aurea, and Turquoise-fronted Parrot Amazona aestiva, exploited Erythrina fusca ripping the flowers off the
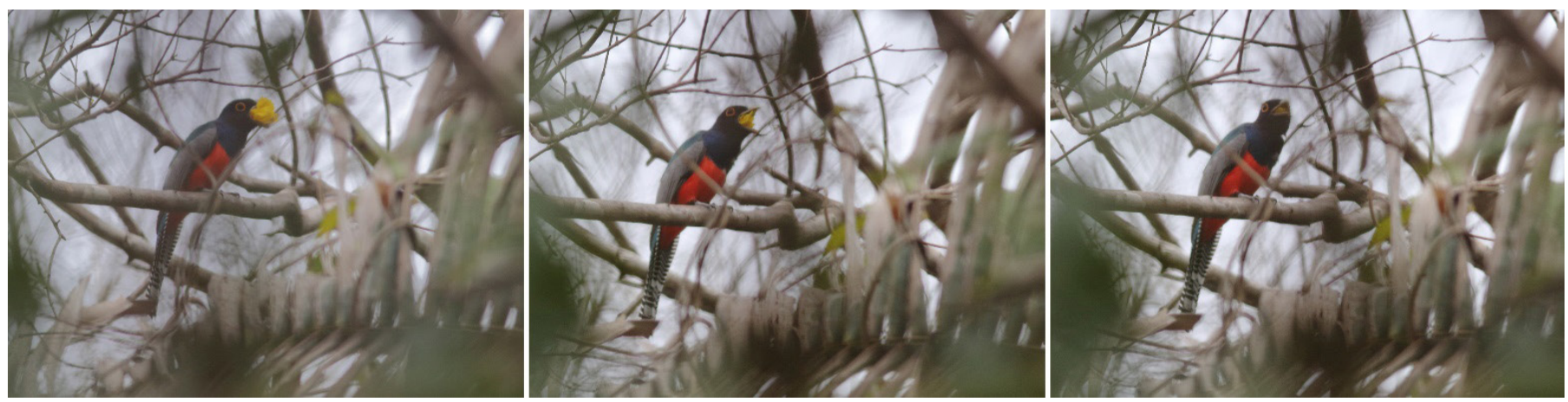

Figure 2. A Blue-crowned Trogon (Trogon curucui) male swallows a whole trumpet tree flower (Handroanthus sp.) in the Cerrado savanna at Brejo do Peixe, 
branch to feed on nectar, while the Chestnut-eared Aracari Pteroglossus castanotis and $R$. toco swallowed the flowers whole (Parrini \& Raposo 2010). On the other hand, the Sayaca Tanager, the Palm Tanager Thraupis palmarum, and the Grayish Saltator Saltator coerulescens were observed tearing off and eat the petals (Parrini \& Raposo 2010). As would be expected, wide-gaped birds swallow the flowers whole, whereas narrow-gaped ones feed on flower pieces.

Despite the apparent rarity and seasonality, feeding on flowers by the Blue-crowned Trogon indicates that this bird searches actively for alternative sources of nutrients to meet water and nutrients requirements during periods of fruit scarcity. However, studies on the relationship between birds and blooming trumpet trees (Handroanthus and Tabebuia) in the Cerrado and Pantanal are still scarce. Both these biomes have an intense dry season when they are vulnerable to extensive wildfires, which may have a significant impact on the abundance of feeding resources for birds during this part of the year. Thus, availability of alternative food, such as flowers, may be fundamental to their survival.

The Blue-crowned Trogon and Green-backed Trogon are phylogenetically close (Espinosa de los Monteros 1998, Moyle 2005), and both species occasionally feed on flowers (Pizo 2007; present paper). The Cuban Trogon Priotelus temnurus is placed among the first branching lineages in the phylogeny of the Neotropical trogons (Espinosa de los Monteros 1998, Moyle 2005), and feed mostly on flowers (Collar 2020). Given the absence of flower-eating in most Trogon species, we submit that this feeding behavior could have been lost throughout the evolution of the variable feeding habits of most Neotropical trogons (Collar 2020, Winkler et al. 2020). Alternatively, florivory is actually a rare behavior and has been mostly unnoticed. We predict that a few additional flower eating Trogon species will be reported with further observational, natural history-oriented studies, especially in biomes with marked seasonal differences.

\section{Acknowledgments}

We are grateful to Fundação de Amparo à Pesquisa e ao Desenvolvimento Científico e Tecnológico do Maranhão (FAPEMA) for financing GG research with a Master's scholarship (BM-05416/19) and MARS with a scientific initiation scholarship BIC-03719/19. To our colleagues at the Ornithology Laboratory for their assistance in the field, and to Juliano do Carmo Silva and Albert Aguiar for making available important references on the subject of this paper. Stephen Ferrari improved the English version. Two anonymous reviewers commented on the manuscript.

\section{Author Contributions}

Gustavo Gonsioroski: Contribution to data collection; manuscript preparation; contribution to critical revision, adding intellectual content.

Ivan Sazima: Contribution to data collection; manuscript preparation; contribution to critical revision, adding intellectual content.

Marcos Augusto Rodrigues Silva: Contribution to data collection; manuscript preparation.

Flávio Kulaif Ubaid: Manuscript preparation; contribution to critical revision, adding intellectual content.

\section{Conflicts of Interest}

The authors declare that they have no conflict of interest related to the publication of this manuscript.

\section{Ethics}

We declare that the procedures used in this study have no conflict with the Brazilian Laws regarding the use of vertebrates in scientific research.

\section{Data availability}

Besides the map, photographs and descriptions included here, other data was compiled from published literature, and appropriated cited along the manuscript.

\section{References}

BAKER, H.G. \& BAKER, I. 1983. Floral nectar sugar constituents in relation to pollinator type. In Handbook of experimental pollination biology (C.E. Jones, R. J. Little, eds.) Van Nostrand Reinhold Co., New York, p. 117-141.

BARROS, M.G. 2001. Pollination ecology of Tabebuia aurea (Manso) Benth. Hook. and T. ochracea (Cham.) Standl. (Bignoniaceae) in Central Brazil cerrado vegetation. Revista Brasileira de Botânica 24: 255-261.

BURGESS K.H. 1991. Florivory: the ecology of flower feeding insects and their host plants. PhD Thesis, Harvard University, Cambridge.

COLLAR, N. 2020. Blue-crowned Trogon (Trogon curucui). In Birds of the World. Cornell Lab of Ornithology (J. del Hoyo, A. Elliott, J. Sargatal, D.A. Christie, E. de Juana, eds.) Ithaca. https://doi.org/10.2173/bow.blctro1.01 (last access in 2 May 2020)

DEL HOYO, J., KIRWAN, G.M., COLLAR N., CHRISTIE D.A. \& SHARPE, C.J. 2020. Blue-throated Piping-Guan (Pipile cumanensis). In Birds of the World. Cornell Lab of Ornithology (S.M. Billerman, B.K. Keeney, P.G. Rodewald, T.S. Schulenberg, eds.), Ithaca. https://doi.org/10.2173/bow. btpgua1.01 (last access in 2/05/2020)

ESPINOSA DE LOS MONTEROS, A.E. 1998. Phylogenetic relationships among the trogons. The Auk 115: 937-958.

GALETTI, M., LAPS, R. \& PIZO, M.A. 2000. Frugivory by Toucans (Ramphastidae) at two altitudes in the Atlantic Forest of Brazil. Biotropica 32: $842-850$.

GALETTO, L. \& BERNARDELLO, G. 2003. Nectar sugar composition in angiosperms from Chaco and Patagonia (Argentina): an animal visitor's matter? Plant Systematics and Evolution 238: 69-86.

MENDES, D.O.F., MENDES, L.F.P., SOUZA, E.O. \& AOKI, C. 2017. Flores de paratudo (Tabebuia aurea) (Bignoniaceae) como recurso alimentar para aves no Pantanal sul, Brasil. Boletim do Museu Paraense Emílio Goeldi. Ciencias Naturais 12: 295-299.

MLCEK, J.M. \& ROP, O. 2011. Fresh edible flowers of ornamental plants - a new source of nutraceutical foods. Trends in Food Science \& Technology 22: 561-569.

MOYLE, R.G. 2005. Phylogeny and biogeographical history of Trogoniformes, a pantropical bird order. Biological Journal of the Linnean Society 84: 725-738.

PARRINI, R. 2015. Quatro estações: História natural das aves na Mata Atlântica - uma abordagem trófica. Technical Books, Rio de Janeiro.

PARRINI, R. \& PACHECO, J.F. 2013. Comportamentos de forrageamento das aves na exploração de recursos florais de Tabebuia heptaphylla (Bignoniaceae) no Pantanal de Mato Grosso, Brasil. Atualidades Ornitológicas 172: 4-7.

PARRINI, R. \& RAPOSO, M.A. 2008. Associação entre aves e flores de duas espécies de árvores do gênero Erythrina (Fabaceae) na Mata Atlântica do sudeste do Brasil. Iheringia - Série Zoologia 98: 123-128. 
PARRINI, R. \& RAPOSO, M.A. 2010. Aves explorando flores de Erythrina fusca (Leguminosae, Fabaceae) durante a estação seca no Pantanal de Mato Grosso. Iheringia - Serie Zoologia 100: 97-101.

PIZO, M.A. 2007. The relative contribution of fruits and arthropods to the diet of three trogon species (Aves, Trogonidae) in the Brazilian Atlantic Forest. Revista Brasileira de Zoologia 24: 515-517.

RAGUSA-NETTO, J. 2005. Extensive consumption of Tabebuia aurea (Manso) Benth. \& Hook. (Bignoniaceae) nectar by parrots ina Tecoma Savanna in the southern Pantanal (Brazil). Brazilian Journal of Biology 65: 339-334.

RAGUSA-NETTO, J. 2006. Abundance and frugivory of the Toco Toucan (Ramphastos toco) in a gallery forest in Brazil's southern Pantanal. Brazilian Journal of Biology 66: 133-142.

REMSEN JR, J.V. \& HYDE, M.A., CHAPMAN, A. 1993. The diets of Neotropical trogons, motmots, barbets and toucans. The Condor 95: 178-192.

RILEY, S.M. \& SMITH, K.G. 1986. Flower eating by Emerald Toucanets in Costa Rica. The Condor 88: 396-397.

SAZIMA, I. \& SAZIMA, M. 2007. Petiscos florais: pétalas de Acca sellowiana (Myrtaceae) como fonte alimentar para aves em área urbana no Sul do Brasil. Biota Neotropica 7: 307-311.

SCHUBART, O., AGUIRRE, A.C. \& SICK, H. 1965. Contribuição para o conhecimento da alimentação das aves brasileiras. Arquivos de Zoologia 12: $95-249$.

SICK, H. 1997. Ornitologia brasileira. Ed. Nova Fronteira, Rio de Janeiro.

SILVA, J.F. \& RUBIO, T.C. 2007. Combretum lanceolatum como recurso alimentar para aves no Pantanal. Revista Brasileira de Ornitologia 15: 459-460.
SILVA, P.A. 2019 Flower eating by the Toco Toucan (Ramphastos toco) in an anthropogenic landscape during the dry season. Ornitologia Neotropical 30: 51-55.

SILVA, P.A., MELO, C. \& BRITO, L. 2015. Calyx-water consumption by Blueand-yellow Macaws in Spathodea campanulata (Bignoniaceae) floral buds. Ornitología Neotropical 26: 201-206.

SOUZA, D.A.S., LENZI, M. \& OITH, A.I. 2004. Contribuição à ecologia da polinização de Tabebuia pulcherrima (Bignoniaceae) em área de restinga, no sul de Santa Catarina. Biotemas 17: 47-66.

TARIFA, J.R. 1986. O sistema climático do Pantanal. Da compreensão do sistema à definição de prioridades de pesquisa climatológica, p. 9-27. Anais I Simpósio sobre Recursos Naturais e Sócio-econômicos do Pantanal. EMBRAPA, Corumbá.

TERBORGH, J. 1986. Keystone plant resources in the tropical forest. Pp. 330-344 in Conservation biology: the science of scarcity and diversity. (M. E. Soulé, ed.) Sinauer Associates, Sunderland.

VALTUILLE, T., UBAID, F.K., SANTANA, M.L.C., CASTRO, S.V., BRANDÃO, R.A., FRANCYOSO, R.D., CAVALCANTI, R.B., CARQUEJO, J. \& ABRÃO, L. 2017. Conservação do jacu-do-nordeste: um estudo na Caatinga brasileira. Ed. Samec, Florianópolis.

WINKLER, D.W., BILLERMAN, S.M. \& LOVETTE, I.J. 2020. Trogons (Trogonidae). In Birds of the World Cornell Lab of Ornithology (S.M. Billerman, B.K. Keeney, P.G. Rodewald, T.S. Schulenberg, eds.) Ithaca. https://doi.org/10.2173/bow.trogon1.01 (last access in 27/06/2020)

Received: 04/11/2020

Revised: 12/05/2021

Accepted: 16/05/2021

Published online: 09/06/2021 